\title{
Design and simulation of a hybrid system based on renewable energy for hydrogen production
}

\author{
Reza Alayi ${ }^{1 凶}$, Mehrdad Ahmadi Kamarposhti ${ }^{1}$, Majid Gharibi ${ }^{1}$, Sara Abbasi zanghaneh ${ }^{1}$, and \\ Mehdi Jahangiri ${ }^{1}$
}

${ }^{1}$ Departement of mechanics, Germi Branch, Islamic azad university, Germi, Iran

$\otimes_{\text {reza.alayi@yahoo.com }}$

\begin{abstract}
Transitioning to renewable energy is part of the answer to, on the one hand, growing industrial development and the rising demand for energy and, on the other, environmental concerns and the need to preserve fossil fuel resources for future generations. This research focuses on the potential for integrating hydrogen storage into a highly reliable renewable energy system. The purpose of this study is to determine the potential of renewable energy in an Iranian location, in a project that looks at a power grid in various connected and disconnected scenarios involving hydrogen storage. The energy potential is identified: annual production capacity is $2218818 \mathrm{~kW}$, requiring a total investment outlay of US\$697,624.
\end{abstract}

Keywords: fossil fuel resources, renewable energy, investment cost, hydrogen storage.

\section{Introduction}

Dependence on fossil fuels is higher than ever before, as more than $90 \%$ of the world's energy consumption comes from fossil fuels $[1,2,3]$. Optimal production and use of energy are key factors in the growth and development of countries [4, 5, 6, 7]. Of particular importance are the quality and reliability of supply. The development and expansion of renewable energy are beneficial for economic, social and environmental development, which are key factors in achieving sustainable development in any country $[8,9,10]$. The use of new energy technologies, such as nuclear, solar and wind, can reduce dependence on fossil fuels, reduce emissions of polluting gases from the manufacturing and energy sectors and of greenhouse gases $[11,12,13]$. Concerns about climate change and its relationship to fossil fuel consumption and rising greenhouse gases have given the problem a higher global profile[14, 15]. The crises of the 1970s underlined the vulnerability of industrialized nations as regards oil supply security, bolstering the case for renewable energy technologies $[16,17]$.
According to Vaziri Rad et al. [18] rural electrification is a key challenge in achieving access to electricity for the entire population of Iran. The current study focuses on finding an optimal renewable energy system to meet the load of a small village. This village faces frequent power outages, a common occurrence in remote villages around the world. A hybrid photovoltaics/wind turbine/biogas generator/fuel cell renewable energy system is proposed and analyzed for both stand-alone and on-grid application. Fuel cells are used alongside a hydrogen tank, batteries, and a reformer or an electrolyzer, to act as storage devices and backup component. The main goal is to find an optimal configuration that can meet the electricity demand and be satisfactory from both an economic and environmental point of view. The results indicated that using solar, wind and biogas is the most affordable method and that adding a fuel cell to this configuration would increase costs by 33$37 \%$, but would also improve system flexibility. Using a reformer is more efficient and about $6 \%$ less costly, but creates more pollution. The cost of energy for a stand-alone system with reformer was calculated to be 0.164 to $0.233 \$ / \mathrm{kWh}$, while the on-grid system cost of energy was $0.096-0.125 \$ / \mathrm{kWh}$. Cristian et al. [19] studied the design of hybrid power systems using the HOMER simulator for different renewable energy sources. Buonomano et al. [20] selected a hybrid renewable system based on wind and solar energy coupled with electrical storage: dynamic simulation and economic assessment. Zhang et al. [21] studied optimization with a simulated annealing algorithm of a hybrid system for renewable energy including battery and hydrogen storage. Budak et al. [22] made a comparative study of PV/PEM fuel cell hybrid energy system based on methanol and water electrolysis. Mohammed et al. [23] studied optimal design and energy management of a hybrid power generation system based on wind/tidal/Pv sources: Case study for the French island of Ouessant. Another study [24] looked at optimization and evaluation of a wind, so- 
lar and fuel cell hybrid system supplying electricity to a remote district on the national grid. Gökçek et al. [25] performed a techno-economical evaluation of a hydrogen refuelling station powered by a wind-PV hybrid power system, in a case study for Izmir-Ceșme. Other research has been done to optimize renewable energy at the lowest cost $[26,27,28,29]$.

Potentiometric means extracting the values of each of the renewable energies and then selecting one or more sources of potential energy from the available resources. As selecting the right type of renewable energy in an area calls for careful estimation of the potential of renewable energies in that area, knowing the potential of each type of renewable energies in an area contributes to the decision on the type of primary system applicable in an area. In determining the potential for renewables, great care must be taken as regards the base information on which the analysis is based and how it is used. The potential of a particular renewable in an area is usually estimated based on the atlas provided for that energy in the locality. If atlas data are not available, field studies will be necessary to estimate the potential of the region's renewable resources, because in the initial design of renewable systems what is important is accurate hour-to-hour information on the renewable potential (wind speed, sunlight intensity, etc.). Furthermore, the geographical and climatic characteristics of the area must be precisely determined. The point to be noted about the potential of renewables in a region is that, to be valid, the calculations have to be based on a varied geographic approach . It is preferable to have complete data on renewable energy sources based on field studies for at least a one year period. Thus, when assessing renewable energy sources for possible use in a locality, the following are needed:

- Potential of renewable resources in an area and their effective role in the selection of renewable energy systems,

- Variability of the potential renewable energy sources in the area,

- Raw, unprocessed data on renewable energy sources.

In this study, the potential assessment was performed first, followed by an assessment of the renewable energies.

\section{Materials and methods}

\subsection{The site examined}

The urban area of Karaj, centered on Karaj city, is a major city $40 \mathrm{~km}$ west of Tehran. Karaj lies at an alti- tude of 1300 meters above sea level and is surrounded by the rugged Alborz Mountains. The population of urban Karaj based on the census of 2016 was 1.6 million, rising to 1.97 million including the suburbs. Karaj is Iran's fourth most populated city and the 21st most populous metropolis in the Middle East.

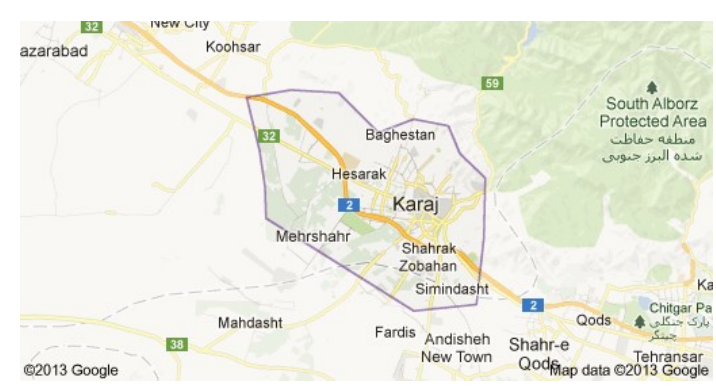

Figure 1: Geographical profile of Karaj

\subsection{General description of the model}

The study determined the potential available at the site under study, considered the high potential of renewable energy as a source of electrical power generation, then looked at the form used to supply the required load. Initial studies at the site under study identified solar and wind energy as high potential sources, which can be seen in subsequent sections on the amount of sunlight and wind. In the next step, the photovoltaic cell model used was coded in MAT$\angle A B$, and HOMER software was used to simulate the system, factoring in data on the amount of sunlight, wind and electricity required. The wind and radiation intensity data for the study area (Tehran) was taken from the NASA site. The data on the electricity required was obtained from the Ministry of Energy. The equipment needed for the system was determined. The objective function was implemented with the optimal approach from the economic point of view while being able to reliably meet the maximum load demanded. The study also looks at the production of hydrogen as a clean fuel, which can be considered as a fuel cell input source for generating thermal energy or for use in a gas turbine or as car fuel.

\section{Solar radiation intensity}

The solar radiation intensity data for Karaj for 2017/18 was obtained from the NASA site and inputted in Homer software. The daily solar radiation in this region was $4.89 \mathrm{KWh} / \mathrm{m}^{2} / \mathrm{d}$, as shown in Fig. 2.

Figure 2 shows that the highest radiation intensity is 7.35 in June and the lowest is 2.38 in December, 


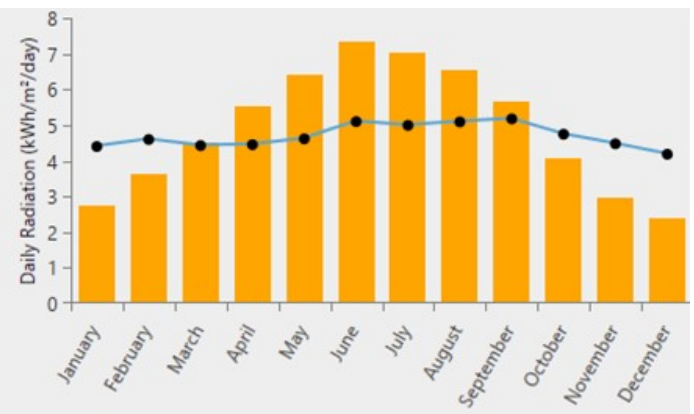

Figure 2:

Average solar radiation intensity for the studied site (REEEO)

with average air purity percentage of 0.636 and 0.52 , respectively.

\subsection{Wind intensity}

Based on the issues discussed in the potential assessment, this section determined the wind intensity at the site. Fig. 3 below shows the wind data at $50 \mathrm{~m}$ above ground level for a one year period.

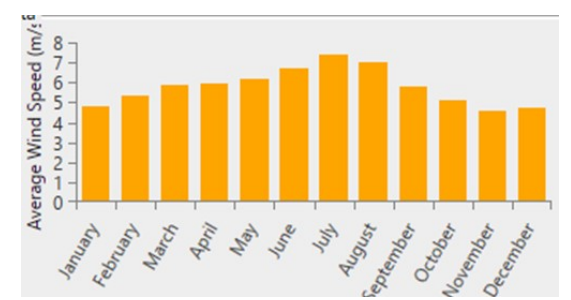

Figure 3: Mean wind chart for the site (REEEO)

The above graph shows that the mean wind speed for this area is $5.79 \mathrm{~m} / \mathrm{s}$, which shows high potential for operation in this area. The highest and lowest winds were in July and January with values of 7.37 and 4.8 $\mathrm{m} / \mathrm{s}$. Figure 4 shows the wind speed changes at various altitudes.

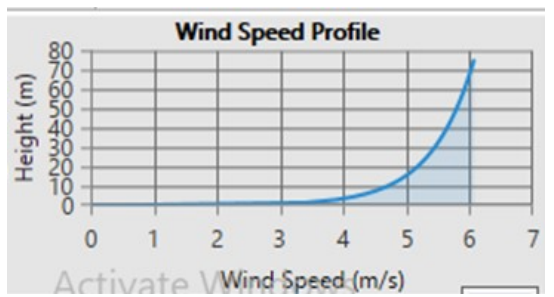

Figure 4: Wind speed as a function of height at the site

\section{Electrical demand}

To simulate with greater accuracy and to achieve more realistic results the electric load required is $11.26 \mathrm{kw}$
/ d per day with peak load of $2.09 \mathrm{kw}$, which is seen for one year in detail in Fig. 5.

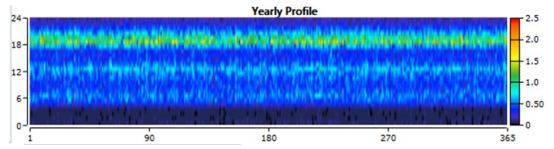

Figure 5: Electrical charge diagram (visiting the examined site)

\subsection{The model of the intended system}

\subsubsection{Scenario One: off grid}

The photovoltaic cells are connected to a DC bus and the wind turbine due to their DC power output, and a DC / AC converter transforms the total power produced by these units to $A C$ power for consumer use in the $A C$ bus. By applying the above information to the software as well as the cost of the equipment used in the hybrid system, one can consider the configuration as follows.

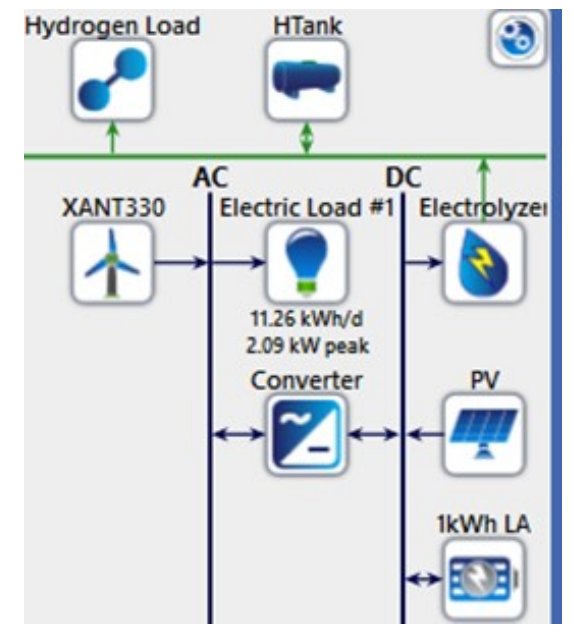

Figure 6: Schematic chart of the hybrid wind-solar system with hydrogen storage

\section{Scenario 2: on grid}

The photovoltaic cells are connected to the AC bus to generate $D C$ power, the wind turbine and the grid to the $A C$ bus, and are connected to the $A C$ bus by a $D C$ / $A C$ converter of the total power generated by these units for $A C$ bus. By applying the above information to the software as well as the cost of the equipment used in the hybrid system, one can consider the configuration as follows. 


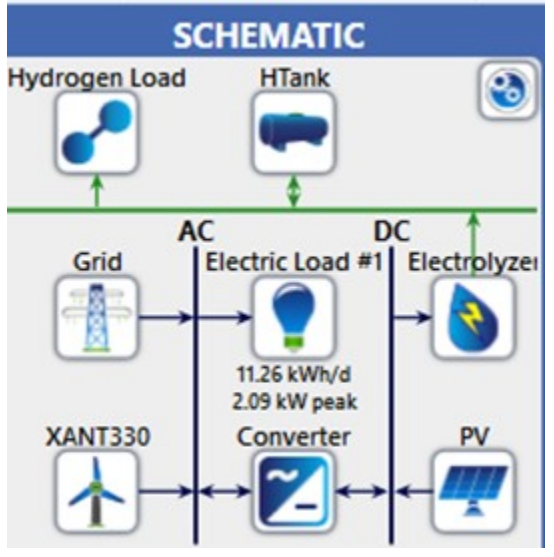

Figure 7: Schematic chart of the solar-wind hybrid system considering grid-connected state

\section{Results}

\subsection{A. Overall results}

After simulating the system in Homer software, results were obtained for two objectives: lowest investment cost and high reliability. The system has a designed lifetime of 20 years.

Based on the results, the Net Present Cost (NPC) of the solar and wind-powered hydrogen storage system was $\$ 449523$ and the year-round maintenance cost was $\$ 6662$ over the 20 years of operation. The total cost per $\mathrm{kWh}(\mathrm{COE})$ of the system was $\$ 8.47$, which required $28.8 \mathrm{~kW}$ of photovoltaic cells and a 2-unit $10 \mathrm{kWh}$ wind turbine with a $13.6 \mathrm{~kW}$ converter. The table below indicates the optimal solutions for the second scenario, i.e. grid connected mode.

Based on the results, the NPC of the wind and solar system with hydrogen storage was $\$ 697624$ and the year-round maintenance cost was $\$ 93836$ over the 20-

Table 1: The results obtained from HOMER software for the first scenario hybrid system

\begin{tabular}{lr}
\hline Equipment & Quantity \\
\hline Solar cell & $28.8 \mathrm{kw}$ \\
Wind turbine & 2 \\
Battery & $10 \mathrm{kwh}$ \\
Invertor & $13.6 \mathrm{kw}$ \\
$\mathrm{H}$ tank & $200 \mathrm{~kg}$ \\
Electrolyzer & $200 \mathrm{kw}$ \\
Initial capital $(\$)$ & 363402 \\
Operating cost $(\$ / \mathrm{y})$ & 6662 \\
Total NPC $(\$)$ & 449523 \\
$\operatorname{COE}(/ \$ \mathrm{KWH})$ & 8.47 \\
\hline
\end{tabular}

Table 2: The results obtained from HOMER software for the system hybrid in the second scenario

\begin{tabular}{lr}
\hline Equipment & Quantity \\
\hline Solar cell $(\mathrm{KW})$ & 36 \\
Grid$(\mathrm{KW})$ & 999999 \\
Wind turbine & 3 \\
H2 tank $(\mathrm{Kg})$ & 200 \\
Invertor $(\mathrm{KW})$ & 12 \\
Electrolyzer $(\mathrm{KW})$ & 200 \\
Initial capital $(\$)$ & 515441 \\
Operating cost $(\$ / y)$ & 93836 \\
Total NPC $(\$)$ & 697624 \\
COE $(/ \$ \mathrm{KWH})$ & 0.02 \\
\hline
\end{tabular}

year period of operation.

The total cost per kWh (COE) cost of the system was $\$ 0.02$, which required on-demand load of $36 \mathrm{~kW}$ of photovoltaic cells and a 3-unit wind turbine with a $12 \mathrm{~kW}$ converter. Given the decision parameters of the second scenario, the analysis is acceptable and the analysis for the second scenario is continued.

\subsection{The cost of investing in the com- ponents of the hybrid system}

The total construction cost at NPC will be $\$ 697624$ over the 20-year lifetime of the solar / wind hybrid power plant.

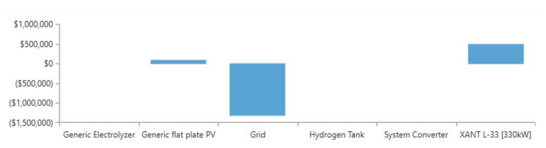

Figure 8: Cost of investment by component of the first scenario hybrid system

\subsection{Operation rate of the hybrid sys- tem tools examined}

In independent mode, the only sources of generation are photovoltaic cell and wind turbine power. The power output of this equipment over a one-year period can be seen in Figure 9.

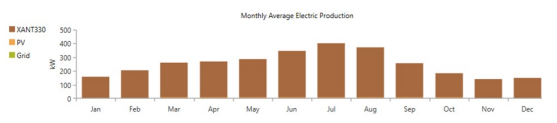

Figure 9: Electricity generation rate during the year 
Given the above graph, the generation capacity per year is $2218818 \mathrm{~kW}$ which matches the total load needed by the system. Figs. 10 and 11 show the electricity generation by the system every day.

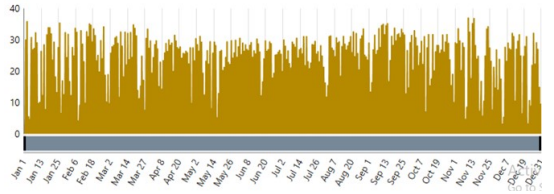

Figure 10: Power generation rate by photovoltaic cell per day

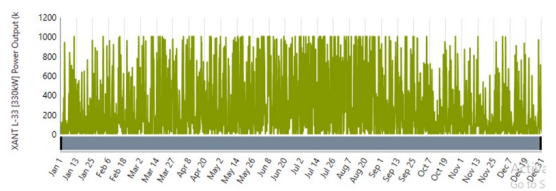

Figure 11: Power generation rate by wind turbine per day

Fig. 12 shows the hydrogen produced per day of the year that can be used for storage and use in fuel cells or for sale.

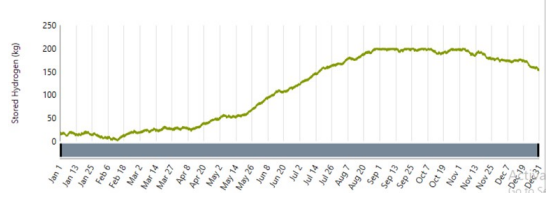

Figure 12: The amount of hydrogen produced

Fig. 13 shows the operating hours of the converter.

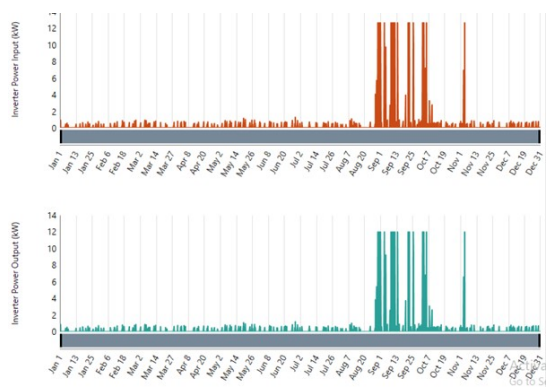

Figure 13: DC-AC converter operating hours per year

\section{Conclusion}

The study first assessed the potential of the studied area, leading to identifying wind and solar as po- tential renewable sources. Wind and solar radiation data were extracted from reliable sources and used in Homer software. In this configuration, the storage device was not used to store surplus energy, and the surplus energy was used to generate hydrogels; thus, the system was considered as connected to the grid. After running the program, the following results were obtained.

- Using renewable energy to produce hydrogen is a proper choice

- The rate of return on capital is much lower in grid-connected state than that of disconnected state.

- The wind energy potential in the site examined is much greater than solar energy; thus, most power generation is related to the wind turbine.

- By using wind turbine as a power source, the costs of the converter will greatly diminish, which will reduce the rate of return on capital and power-generation cost.

\section{References}

[1] Noel Healy and John Barry. Politicizing energy justice and energy system transitions: Fossil fuel divestment and a "just transition". Energy Policy, 108:451-459, sep 2017.

[2] Jahanbin F Alayi, R. Generation Management Analysis of a Stand-alone Photovoltaic System with Battery. Renewable Energy Research and Application, 1(2), 2020.

[3] Kyra Bos and Joyeeta Gupta. Climate change: the risks of stranded fossil fuel assets and resources to the developing world. Third World Quarterly, 39(3):436-453, oct 2017.

[4] Shamel A. Kasaeian A. Harasii H. \& Topchlar M. A Alayi, R. The role of biogas to sustainable development (aspects environmental, security and economic). Journal of Chemical and Pharmaceutical Research, 8(4), 2016.

[5] Sarbjit Giddey, Sukhvinder P.S. Badwal, and HyungKuk Ju. Polymer Electrolyte Membrane Technologies Integrated With Renewable Energy for Hydrogen Production. In Current Trends and Future Developments on (Bio-) Membranes, pages 235-259. Elsevier, 2019.

[6] Harasii H. Alayi R. Delbari S. Sadeghzadeh M. Javaherbakhsh A Pourderogar, H. Modeling and Technical Analysis of Solar Tracking System to Find Optimal Angle for Maximum Power Generation using MOPSO Algorithm. Renewable Energy Research and Application, 1(2), 2020. 
duction based on renewable energy: A techno-

[7] Ankica Kovač, Doria Marciuš, and Luka Budin. Solar hydrogen production via alkaline water electrolysis. International Journal of Hydrogen Energy, 44(20):9841-9848, apr 2019.

[8] Reza Alayi, Alibakhsh Kasaeian, and Farideh Atabi. Thermal analysis of parabolic trough concentration photovoltaic/thermal system for using in buildings. Environmental Progress \& Sustainable Energy, 38(6):13220, apr 2019.

[9] Mohammad Jafar Hadidian Moghaddam, Akhtar Kalam, Saber Arabi Nowdeh, Abdollah Ahmadi, Manoochehr Babanezhad, and Sajeeb Saha. Optimal sizing and energy management of standalone hybrid photovoltaic/wind system based on hydrogen storage considering LOEE and LOLE reliability indices using flower pollination algorithm. Renewable Energy, 135:1412-1434, may 2019.

[10] T.R. Ayodele, A.S.O. Ogunjuyigbe, and T.Y Ibitoye. Optimal selection of pumped hydro storage based renewable energy generator(s) for isolated community using binary sort and search algorithm. Renewable Energy Focus, 28:100-111, mar 2019 .

[11] Reza Alayi, Alibakhsh Kasaeian, and Farideh Atabi. Optical modeling and optimization of parabolic trough concentration photovoltaic/thermal system. Environmental Progress \& Sustainable Energy, 39(2), jul 2019.

[12] Shamel A. \& Alayi R Kasaeian, A. Simulation and economic optimization of wind turbines and photovoltaic hybrid system with storage battery and hydrogen tank (case study the city of Yazd). Journal of Current Research in Science, 3(5), 2015.

[13] Weiping Zhang, Akbar Maleki, Marc A. Rosen, and Jingqing Liu. Sizing a stand-alone solarwind-hydrogen energy system using weather forecasting and a hybrid search optimization algorithm. Energy Conversion and Management, 180:609-621, jan 2019.

[14] Sobhani E. Najafi A Alayi, R. Analysis of Environmental Impacts on the Characteristics of Gas Released from Biomass. Anthropogenic Pollution Journal, 4(1), 2020.

[15] Sema Z. Baykara. Hydrogen: A brief overview on its sources production and environmental impact. International Journal of Hydrogen Energy, 43(23):10605-10614, jun 2018.

[16] Z. Abdin and W. Mérida. Hybrid energy systems for off-grid power supply and hydrogen pro- economic analysis. Energy Conversion and Management, 196:1068-1079, sep 2019.

[17] Tanay Sıdkı Uyar and Doğancan Beșikci. Integration of hydrogen energy systems into renewable energy systems for better design of $100 \%$ renewable energy communities. International Journal of Hydrogen Energy, 42(4):2453-2456, jan 2017.

[18] Mohammad Amin Vaziri Rad, Roghaye Ghasempour, Parisa Rahdan, Soroush Mousavi, and Mehrdad Arastounia. Techno-economic analysis of a hybrid power system based on the costeffective hydrogen production method for rural electrification a case study in Iran. Energy, 190:116421, jan 2020.

[19] Hoarca Cristian, Nicu Bizon, and Badita Alexandru. Design of hybrid power systems using HOMER simulator for different renewable energy sources. In 2017 9th International Conference on Electronics Computers and Artificial Intelligence (ECAI). IEEE, jun 2017.

[20] Annamaria Buonomano, Francesco Calise, Massimo Dentice d'Accadia, and Maria Vicidomini. A hybrid renewable system based on wind and solar energy coupled with an electrical storage: Dynamic simulation and economic assessment. Energy, 155:174-189, jul 2018.

[21] Weiping Zhang, Akbar Maleki, Marc A. Rosen, and Jingqing Liu. Optimization with a simulated annealing algorithm of a hybrid system for renewable energy including battery and hydrogen storage. Energy, 163:191-207, nov 2018.

[22] Yağmur Budak and Yılser Devrim. Comparative study of PV/PEM fuel cell hybrid energy system based on methanol and water electrolysis. Energy Conversion and Management, 179:46-57, jan 2019.

[23] O. H. Mohammed, Y. Amirat, M. E. H. Benbouzid, and G. Feld. Optimal Design and Energy Management of a Hybrid Power Generation System Based on Wind/Tidal/PV Sources: Case Study for the Ouessant French Island. In Smart Energy Grid Design for Island Countries, pages 381-413. Springer International Publishing, 2017.

[24] Reza Alayi, Alibakhsh Kasaeian, Atabak Najafi, and Eskandar Jamali. Optimization and evaluation of a wind solar and fuel cell hybrid system in supplying electricity to a remote district in national grid. International Journal of Energy Sector Management, 14(2):408-418, oct 2019. 
[25] Murat Gökçek and Cihangir Kale. Technoeconomical evaluation of a hydrogen refuelling station powered by Wind-PV hybrid power system: A case study for Izmir-Ceșme. International Journal of Hydrogen Energy, 43(23):1061510625, jun 2018.

[26] Kamal Anoune, Mohsine Bouya, Abdelali Astito, and Abdellatif Ben Abdellah. Sizing methods and optimization techniques for PV-wind based hybrid renewable energy system: A review. Renewable and Sustainable Energy Reviews, 93:652673 , oct 2018.

[27] Sarangthem Sanajaoba Singh and Eugene Fernandez. Modeling size optimization and sensitivity analysis of a remote hybrid renewable energy system. Energy, 143:719-731, jan 2018.

[28] A. Can Duman and Önder Güler. Technoeconomic analysis of off-grid PV/wind/fuel cell hybrid system combinations with a comparison of regularly and seasonally occupied households. Sustainable Cities and Society, 42:107-126, oct 2018.

[29] Zehra Ural Bayrak, Gökay Bayrak, Mahmut Temel Ozdemir, Muhsin Tunay Gencoglu, and Mehmet Cebeci. A low-cost power management system design for residential hydrogen \& solar energy based power plants. International Journal of Hydrogen Energy, 41(29):1256912581, aug 2016.

[30] Junmei Zhou, Zhixiong Xue, Ziyun Du, Teri Melese, and Paul D. Boyer. Relationship of tightly bound ADP and ATP to control and catalysis by chloroplast ATP synthase. Biochemistry, 27(14):5129-5135, jul 1988.

[31] Paul D. Boyer. Energy Life, and ATP (Nobel Lecture). Angewandte Chemie International Edition, 37(17):2296-2307, sep 1998.

[32] K Zinszer, K Morrison, A Verma, and JS Brownstein. Spatial Determinants of Ebola Virus Disease Risk for the West African Epidemic. PLoS Curr, 9, Mar 2017.

[33] Holger Huitenga and Eric R. Norster. Development Approach to the Dry Low Emission Combustion System of MAN Diesel and Turbo Gas Turbines. In Volume 4A: Combustion Fuels and Emissions. American Society of Mechanical Engineers, jun 2014.

[34] Alessio Suman, Nicola Casari, Elettra Fabbri, Michele Pinelli, Luca di Mare, and Francesco Montomoli. Gas Turbine Fouling Tests: Review Critical Analysis, and Particle Impact Behavior
Map. Journal of Engineering for Gas Turbines and Power, 141(3), nov 2018.

[35] Remy Rigo-Mariani, Chuan Zhang, Alessandro Romagnoli, Markus Kraft, K. V. Ling, and Jan M. Maciejowski. A Combined Cycle Gas Turbine Model for Heat and Power Dispatch Subject to Grid Constraints. IEEE Transactions on Sustainable Energy, pages 1-1, 2019.

[36] Terence Hazel, Graeme Peck, and Hans Mattsson. Industrial Power Systems Using Dry Low Emission Turbines. IEEE Transactions on Industry Applications, 50(6):4369-4378, nov 2014.

[37] Medhat A. Nemitallah, Sherif S. Rashwan, Ibrahim B. Mansir, Ahmed A. Abdelhafez, and Mohamed A. Habib. Review of Novel Combustion Techniques for Clean Power Production in Gas Turbines. Energy \& Fuels, 32(2):979-1004, jan 2018.

[38] Ahmed Abdelhafez, Sherif S. Rashwan, Medhat A. Nemitallah, and Mohamed A. Habib. Stability map and shape of premixed $\mathrm{CH} 4 / \mathrm{O} 2 / \mathrm{CO} 2$ flames in a model gas-turbine combustor. Applied Energy, 215:63-74, 2018.

[39] Serhiy I. Serbin, Igor B. Matveev, and Ganna B. Mostipanenko. Investigations of the Working Process in a "Lean-Burn" Gas Turbine Combustor With Plasma Assistance. IEEE Transactions on Plasma Science, 39(12):3331-3335, dec 2011.

[40] Challenges in using waste heat recovery and DLE combustion to reduce $\mathrm{CO} 2$ \& NOX emissions - IEEE Conference Publication. https://ieeexplore.ieee.org/abstract/document/5164864. Accessed on Tue, December 17, 2019.

[41] James C. Massey, Zhi X. Chen, and Nedunchezhian Swaminathan. Lean Flame Root Dynamics in a Gas Turbine Model Combustor. Combustion Science and Technology, 191(56):1019-1042, apr 2019.

[42] N. Zettervall, N.A. Worth, M. Mazur, J.R. Dawson, and C. Fureby. Large eddy simulation of $\mathrm{CH} 4$-air and $\mathrm{C2H} 4$-air combustion in a model annular gas turbine combustor. Proceedings of the Combustion Institute, 37(4):5223-5231, 2019.

[43] Nicola Aldi, Nicola Casari, Mirko Morini, Michele Pinelli, Pier Ruggero Spina, and Alessio Suman. Gas Turbine Fouling: A Comparison Among 100 Heavy-Duty Frames. Journal of Engineering for Gas Turbines and Power, 141(3), oct 2018.

[44] Amare Desalegn Fentaye, Syed Ihtsham UI-Haq Gilani, Aklilu Tesfamichael Baheta, and YiGuang Li. Performance-based fault diagnosis of 
Aspen HYSYS. Energy Conversion and Manage-

a gas turbine engine using an integrated support vector machine and artificial neural network method. Proceedings of the Institution of Mechanical Engineers Part A: Journal of Power and Energy, 233(6):786-802, nov 2018.

[45] Elias Tsoutsanis and Nader Meskin. Dynamic performance simulation and control of gas turbines used for hybrid gas/wind energy applications. Applied Thermal Engineering, 147:122142, jan 2019.

[46] Mohamed Mustafa Mohamed Iqbal, Sankar Sarumathi, Kovilvazhkai Rajappa Jothi, and Arunachalam Brindadevi. Model order reduction of heavy duty gas turbine power plants with field test parameters. International Transactions on Electrical Energy Systems, 29(2):e2703, sep 2018.

[47] Poorya Keshavarz Mohammadian and Mohammad Hassan Saidi. Simulation of startup operation of an industrial twin-shaft gas turbine based on geometry and control logic. Energy, 183:1295-1313, sep 2019.

[48] W. I. Rowen. Simplified Mathematical Representations of Heavy-Duty Gas Turbines. Journal of Engineering for Power, 105(4):865-869, oct 1983.

[49] R. M. Montañés I. E. Cáceres and L. O. Nord. Flexible operation of combined cycle gas turbine power plants with supplementary firing. Journal of Power Technologies, 98(2), 2018.

[50] Ali Chaibakhsh and Saeed Amirkhani. A simulation model for transient behaviour of heavyduty gas turbines. Applied Thermal Engineering, 132:115-127, mar 2018.

[51] Moksadur Rahman, Valentina Zaccaria, Xin Zhao, and Konstantinos Kyprianidis. Diagnostics-Oriented Modelling of Micro Gas Turbines for Fleet Monitoring and Maintenance Optimization. Processes, 6(11):216, nov 2018.

[52] Do Won Kang and Tong Seop Kim. Model-based performance diagnostics of heavy-duty gas turbines using compressor map adaptation. Applied Energy, 212:1345-1359, feb 2018.

[53] Morteza Montazeri-Gh, Seyed Alireza Miran Fashandi, and Soroush Abyaneh. Real-time simulation test-bed for an industrial gas turbine engine's controller. Mechanics \& Industry, 19(3):311, 2018.

[54] Zuming Liu and Iftekhar A. Karimi. Simulating combined cycle gas turbine power plants in ment, 171:1213-1225, sep 2018.

[55] Thiago S. Pires, Manuel E. Cruz, Marcelo J. Colaço, and Marco A.C. Alves. Application of nonlinear multivariable model predictive control to transient operation of a gas turbine and NOX emissions reduction. Energy, 149:341-353, apr 2018.

[56] Soon Kiat Yee, Jovica V. Milanovic, and F. Michael Hughes. Overview and Comparative Analysis of Gas Turbine Models for System Stability Studies. IEEE Transactions on Power Systems, 23(1):108-118, feb 2008.

[57] Francisco J. Gomez, Miguel Aguilera Chaves, Luigi Vanfretti, and Svein Harald Olsen. MultiDomain Semantic Information and Physical Behavior Modeling of Power Systems and Gas Turbines Expanding the Common Information Model. IEEE Access, 6:72663-72674, 2018.

[58] Di Huang, Jin wei Chen, Deng ji Zhou, Hui sheng Zhang, and Ming Su. Simulation and analysis of humid air turbine cycle based on aeroderivative three-shaft gas turbine. Journal of Central South University, 25(3):662-670, mar 2018.

[59] M. H. M. Tarik, M. Omar, M. F. Abdullah, and R. Ibrahim. Modelling of dry low emission gas turbine using black-box approach. In TENCON 2017 - 2017 IEEE Region 10 Conference. IEEE, nov 2017.

[60] M. Pondini, A. Signorini, V. Colla, and S. Barsali. Analysis of a simplified Steam Turbine governor model for power system stability studies. Energy Procedia, 158:2928-2933, feb 2019.

[61] Dong-Joon Kim, Young-Hwan Moon, Bum-Sun Choi, Heon-Su Ryu, and Hae-Kon Nam. Impact of a Heavy-Duty Gas Turbine Operating Under Temperature Control on System Stability. IEEE Transactions on Power Systems, 33(4):45434552, jul 2018.

[62] S. Balamurugan, N. Janarthanan, and K.R.M. Vijaya Chandrakala. Small and large signal modeling of heavy duty gas turbine plant for load frequency control. International Journal of Electrical Power \& Energy Systems, 79:84-88, jul 2016.

[63] S. Selva Kumar, R. Joseph Xavier, and S. Balamurugan. Small signal modelling of gas turbine plant for load frequency control. In 2016 Biennial International Conference on Power and Energy Systems: Towards Sustainable Energy (PESTSE). IEEE, jan 2016. 
[64] Mohammad Eslami, Mohammad Reza Shayesteh, and Majid Pourahmadi. Optimal Design of PID-Based Low-Pass Filter for Gas Turbine Using Intelligent Method. IEEE Access, 6:15335-15345, 2018.

[65] Siyamak Afshar Khamseh and Alireza Fatehi. Performance monitoring of heavy duty gas turbines based on Bayesian and Dempster-Shafer theory. In 2017 International Conference on Electrical and Information Technologies (ICEIT). IEEE, nov 2017.

[66] Lasantha Meegahapola and Damian Flynn. Characterization of Gas Turbine Lean Blowout During Frequency Excursions in Power Networks. IEEE Transactions on Power Systems, 30(4):18771887, jul 2015.

[67] M. Omar, M. H. M. Tarik, R. Ibrahim, and M. F. Abdullah. Suitability study on using rowen's model for dry-low emission gas turbine operational performance. In TENCON 2017 - 2017 IEEE Region 10 Conference. IEEE, nov 2017.

[68] D. Stawik P. Czop, G. Kost and G. Wszołek. Formulation and identification of first-principle data-driven models. Journal of Achievements in materials and manufacturing Engineering, 44(2), 2011.

[69] P Czop, G Kost, D Sławik, and G Wszołek. Formulation and identification of first-principle datadriven models. Journal of Achievements in materials and manufacturing Engineering, 44(2):179186, 2011.

[70] Inés Encabo Cáceres, Rubén Mocholí Montañés, and Lars Olof Nord. Flexible operation of combined cycle gas turbine power plants with supplementary firing. Journal of Power Technologies, 98(2):188-197, 2018.

[71] P Czop, D Sławik, and G Wszołek. Demonstration of First-Principle Data-Driven models using numerical case studies. Journal of Achievements in Materials and Manufacturing Engineering, 45(2):170-177, 2011.

[72] Robin Winter, Floriane Montanari, Frank Noé, and Djork-Arné Clevert. Learning continuous and data-driven molecular descriptors by translating equivalent chemical representations. Chemical science, 10(6):1692-1701, 2019.

[73] William I Rowen. Simplified mathematical representations of single shaft gas turbines in mechanical drive service. In ASME 1992 international gas turbine and aeroengine congress and exposi- tion. American Society of Mechanical Engineers Digital Collection, 1992.

[74] Harald HW Funke, Nils Beckmann, Jan Keinz, and Sylvester Abanteriba. Comparison of $\mathrm{Nu}-$ merical Combustion Models for Hydrogen and Hydrogen-Rich Syngas Applied for Dry-LowNox-Micromix-Combustion. Journal of Engineering for Gas Turbines and Power, 140(8):081504, 2018.

[75] A Haj Ayed, K Kusterer, HH-W Funke, J Keinz, and D Bohn. CFD based exploration of the drylow-NOx hydrogen micromix combustion technology at increased energy densities. Propulsion and Power Research, 6(1):15-24, 2017.

[76] Harald H. W. Funke, Nils Beckmann, Jan Keinz, and Sylvester Abanteriba. Comparison of $\mathrm{Nu}-$ merical Combustion Models for Hydrogen and Hydrogen-Rich Syngas Applied for Dry-LowNox-Micromix-Combustion. Journal of Engineering for Gas Turbines and Power, 140(8), apr 2018.

[77] J Hermann, M Greifenstein, B Boehm, and A Dreizler. Experimental investigation of global combustion characteristics in an effusion cooled single sector model gas turbine combustor. Flow, Turbulence and Combustion, 102(4):1025-1052, 2019.

[78] R Hackney, SK Sadasivuni, JW Rogerson, and $\mathrm{G}$ Bulat. Predictive Emissions Monitoring System for Small Siemens Dry Low Emissions Combustors: Validation and Application. In ASME Turbo Expo 2016: Turbomachinery Technical Conference and Exposition. American Society of Mechanical Engineers Digital Collection, 2016.

[79] Holger Huitenga and Eric R Norster. Development approach to the dry low emission combustion system of MAN diesel and turbo gas turbines. In ASME Turbo Expo 2014: Turbine Technical Conference and Exposition. American Society of Mechanical Engineers Digital Collection, 2014.

[80] Mohammad Reza Bank Tavakoli, Behrooz Vahidi, and Wolfgang Gawlik. An educational guide to extract the parameters of heavy duty gas turbines model in dynamic studies based on operational data. IEEE Transactions on power systems, 24(3):1366-1374, 2009.

[81] Shamel A. \& Alayi R. Kasaeian, A. Simulation and economic optimization of wind turbines and photovoltaic hybrid system with storage battery and hydrogen tank (case study the city of Yazd). 
Journal of Power Technologies 100 (4) (2020) 331-340

Journal of Current Research in Science, 3(5), 2015.

[82] Generation Management Analysis of a Standalone Photovoltaic System with Battery. 